\title{
Sistem Pakar Memilih Tipe Belajar Anak Retardasi Mental Menggunakan Metode Case Based Reasoning \\ ${ }^{1}$ Khairunnisa Samosir, ${ }^{2}$ Dasril Aldo, ${ }^{3}$ Yeyi Gusla Nengsih \\ ${ }^{1}$ Universitas Graha Nusantara, Padangsidimpuan \\ ${ }^{2}$ Sekolah Tinggi Manajemen Informatika dan Komputer GICI, Batam \\ ${ }^{3}$ Universitas Imelda Medan, Medan \\ Iksamosir35@gmail.com; 202asrilaldo1994@gmail.com; 33yevigusla22@gmail.com;
}

\section{Article Info}

Article history:

Received, 11-01-2021

Revised, 15-01-2021

Accepted, 29-01-2021

\section{Kata Kunci:}

Sistem Pakar

Case Based Reasoning

Tipe Belajar Anak

Retardasi Mental

\begin{abstract}
ABSTRAK
Keterbelakangan mental adalah difabel intelektual yang ditandai dengan kecerdasan berada di bawah rata-rata. Orang yang terkena Retardasi mental dapat mempelajari kemampuan baru, tetapi kecepatan belajarnya sangat lambat. Terdapat permasalahan yang sering terjadi pada pendeteksian bahwa anak mengalami retardasi mental terutama oleh orang tua dikarenakan kurangnya pengetahuan orang tua terhadap hal tersebut sehingga mengakibatkan salahnya dalam memilih tipe belajar yang tepat terhadap anak. Jika hal tersebut dibiarkan berlanjut, maka akan mengakibatkan kondisi mental anak menjadi semakin buruk. Dikarenakan permasalahan tersebut maka ditawarkan solusi berupa aplikasi sistem pakar dengan metode Case Based Reasoning (CBR), metode ini akan mencocokan data gejala penyakit lama dengan data gejala dari yang dikonsultasikan oleh user sehingga dihasilkan angka similarity dari masing-masing jenis Retardasi mental yang akan diteliti. Hasil akhir dari penelitian ini berupa nilai persentase similarity beserta rekomendasi berupa saran dan juga solusi yang akan dilakukan oleh orang tua dalam memberikan pendidikan secara mandiri kepada anaknya yang mengalami retardasi mental. Hasil yang didapat berupa Tunagrahita dengan persentase $0 \%$, Tunadaksa dengan persentase $82,35 \%$, Tunalaras dengan persentase $0 \%$
\end{abstract}

\section{ABSTRACT}

Mental retardation is an intellectual disability characterized by intelligence being below average. People who are mentally retarded can learn new abilities, but the pace of learning is very slow. There are problems that often occur in the detection that children have mental retardation, especially by parents due to the lack of knowledge of the parents about this, resulting in the mistake of choosing the right type of learning for children. If this is allowed to continue, it will result in the child's mental condition getting worse. Due to these problems, a solution is offered in the form of an expert system application with the Case Based Reasoning (CBR) method, this method will match the symptom data of the old disease with the symptom data consulted by the user so that the similarity number of each type of mental retardation will be produced. The final result of this study is the percentage value of similarity along with recommendations in the form of suggestions and solutions that will be carried out by parents in providing independent education to children with mental retardation. The results obtained were in the form of mental retardation with a percentage of $0 \%$, disabled with a percentage of $82.35 \%$, with disabilities with a percentage of $0 \%$.

This is an open access article under the CC BY-SAlicense.

\section{Penulis Korespondensi:}

Dasril Aldo,

Program Studi Sistem Informasi,

Sekolah Tinggi Manajemen Informatika GICI, Batam

Email: dasrilaldo1994@gmail.com 


\section{PENDAHULUAN}

Teknologi di bidang komputerisasi sudah banyak dipergunakan dalam berbagai lini kehidupan. Teknologi sangat membantu berbagai aspek kehidupan, dengan adanya teknologi manusia dapat menciptakan berbagai alat untuk mempermudah pekerjaan manusia. Contoh penerapan teknologi seperti JST untuk menghitung nilai kandungan makanan[1], edukasi pengenalan hewan ovovivipar, ovipar dan vivipar dengan augmented reality [2], teknologi identifikasi kerusakan mobil[3] dan masih banyak lagi. Pada penelitian ini akan diterapkan perkembangan teknologi komputerisasi di bidang kecerdasan buatan yang mampu mengadopsi kepintaran dari seorang manusia. Kecerdasan buatan sering diterapkan dalam hal Fuzzy Logic, Artificial Neural Network, Algoritma genetik, Sistem pakar (Expert System), Agen Cerdas (Intelligent Software Agents), Penalaran komputer berbasis kasus (Case Based Reasoning), Teknologi Bahasa (Language Technology) dan Data Mining [4]. Pada penelitian ini, cabang ilmu yang yang digunakan yaitu sistem pakar.

Menjawab dan memecahkan masalah merupakan tujuan dari sistem pakar yang dirancang untuk menghasilkan sistem agar bisa meniru keahlian pakar [5]. Penelitian mengenai sistem pakar diantaranya yaitu: untuk identifikasi penyakit ikan laut [6], identifikasi dini corona virus disease (COVID-19) [7], pendeteksi penyakit tuberkulosis [8], pendiagnosa penyakit pada tanaman jagung [9], identifikasi hama dan penyakit tanaman singkong [10] dan masih banyak lagi penelitian lainnya. Dalam pembuatan sistem pakar harus terdapat sebuah metode yang berfungsi sebagai mesin inferensi yang dapat mengelola inputan data berupa gejala-gejala yang dapat dipilih oleh user nantinya untuk berkonsultasi. Terdapat banyak metode yang dapat dijadikan mesin inferensi pada sistem pakar diantaranya yaitu: CF, CBR, Forward dan Backward chaining, Bayes, CBR dan masih banyak metode lainnya.

Pada penelitian ini digunakan metode sistem pakar CBR atau disebut juga case-based reasoning. Penalaran berbasis kasus yakni logika berbasiskan terhadap kasus untuk tujuan menyelesaikan permasalahan yang baru dengan cara menyesuaikan dengan solusi yang mirip kepada kasus baru serta dengan kasus sebelumnya. Penelitian sistem pakar dengan menggunakan metode CBR diantaranya: identifikasi penyakit tanaman padi [11], sistem diagnosa kegagalan dalam budidaya ikan konsumsi air tawar [12]. Metode ini melakukan pencocokkan kasus baru dengan kasus yang ada di database penyimpanan kasus, dan temukan satu atau lebih kasus yang mirip dengan penalaran berbasis kasus. Penalaran berbasis kasus bertujuan untuk memecahkan masalah baru dengan menyesuaikan solusi. Kasus sebelumnya dan kasus baru serupa. Kasus baru cocok dengan kasus yang ada di perpustakaan kasus, dan satu atau beberapa kasus serupa ditemukan [13]. Terdapat empat langkah dalam metode CBR, yaitu: Retrieve, Reuse, Retain, Revise [14]. Penerapan sistem pakar dengan metode CBR pada penelitian ini yaitu untuk memilih tipe belajar anak Retardasi mental. Keterbelakangan mental atau difabel intelektual adalah kekurangan kondisi intelektual yang ditandai dengan kecerdasan atau kecerdasan di bawah rata-rata. Penyandang disabilitas intelektual mempelajari keterampilan baru, tetapi kecepatan belajarnya lambat.

Terdapat permasalahan yang sering terjadi pada pendeteksian bahwa anak mengalami retardasi mental terutama oleh orang tua dikarenakan kurangnya pengetahuan orang tua terhadap hal tersebut sehingga mengakibatkan salahnya dalam memilih tipe belajar yang tepat terhadap anak. Jika hal tersebut dibiarkan berlanjut, maka akan mengakibatkan kondisi mental anak menjadi semakin buruk. Terdapat beberapa jenis Retardasi mental, yaitu: Tunagrahita, Tunadaksa, Tunalaras.

\section{METODE PENELITIAN}

Agar proses yang dilakukan penulis melakukan penelitian tidak lari dari topik utama dari pembahasan dan lebih praktis dipahami, urutan proses tersebut akan dilakukan secara sistematis sehingga dapat dijadikan pedoman yang jelas dan sederhana untuk menyelesaikan masalah yang ada. Urutan langkah-langkah yang akan dilakukan dalam penelitian ini ditunjukkan pada Gambar 1. 


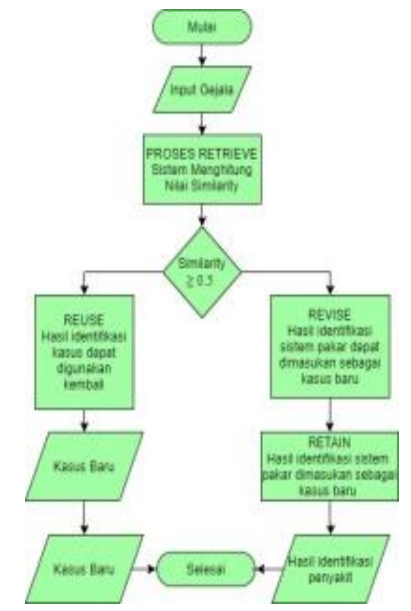

\section{Gambar 1. Flowchart Proses CBR}

Agar proses yang digunakan penulis dalam melakukan penelitian ini tidak menyimpang dari topik utama pembahasan dan lebih praktis dipahami, maka urutan langkah-langkah tersebut akan dilakukan secara sistematis sehingga dapat dijadikan pedoman yang jelas dan sederhana untuk menyelesaikan masalah yang ada. Representasi pengetahuan (knowledge representasi) dari sebuah basis kasus reasoning adalah berupa kumpulan kasus (case base) yang telah terjadi sebelumnya [15]. Diagram alir proses CBR sistem pakar menjelaskan urutan langkah-langkah yang akan dilakukan dalam penelitian ini, dan menunjukkan langkah-langkah awal yang dilakukan oleh pengguna, yaitu memasukkan gejala-gejala yang sudah jelas ke dalam sistem. Kemudian setelah masuk gejala, sistem akan menjalankan proses temu kembali. Jika nilai kemiripan yang diperoleh dari hasil pencarian lebih besar dari atau sama dengan 0,5, maka sistem akan menggunakan kembali data tersebut ke situasi lama untuk digunakan kembali agar dapat segera mendapatkan hasil diagnosis. Pada saat yang sama, jika kemiripan gejala $\leq 0.5$, sistem akan mengimplementasikan proses revisi dan retensi sebagai kasus baru. Penentuan Bobot Gejala:

Gejala Ringan : 1

Gejala Sedang : 3

Gejala Berat : 5

\section{HASIL DAN ANALISIS}

Analisis data bertujuan untuk membatasi topik dan objek yang akan dipelajari, sehingga lebih sistematis dan mudah dipahami. Guna memperoleh data atau informasi dalam studi kasus ini, penulis terlebih dahulu melakukan kegiatan pengumpulan data yang turut menentukan objek penelitian. Tujuan dari analisis masalah adalah untuk menemukan akar penyebab masalah, sehingga didapat bentuk pemecahan masalah dari analisis masalah tersebut. Dalam penelitian ini masalah dapat dianalisis dari kesimpulan analisis data ahli tunagrahita. Salah satu cara untuk mencari solusi atas permasalahan yang akan dijelaskan pada tahap analisis masalah tersebut yakni membangun sistem pakar yang dapat mendiagnosis retardasi mental.

Sejak berkembang (sejak lahir atau masa kanak-kanak), retardasi mental merupakan penyakit kecerdasan rendah (subnormal). Biasanya perkembangan intelektual kurang secara keseluruhan, tetapi gejala utamanya adalah kurangnya kecerdasan. Penelitian ini akan membahas tentang jenisjenis keterbelakangan mental dan interpretasi dari jenis-jenis tersebut.

Tabel 1. Penyakit Retardasi Mental

\begin{tabular}{ccl}
\hline No & Kode Penyakit & Nama Penyakit \\
\hline 1 & RM1 & Tunagrahita \\
2 & RM2 & Tunadaksa \\
3 & RM3 & Tunalaras \\
\hline
\end{tabular}


JSAI : Journal Scientific and Applied Informatics

Vol. 4, No. 01, Januari 2021, hal. 95 105

E-ISSN: 2614-3054; P-ISSN: 2614-3062, accredited by Kemenristekdikti, Sinta 5

DOI: 10.36085

Berikut pengelompokan jenis dapat dibagi tiga, yaitu: Pengelompokan jenis ringan dengan bobot parameter $(w): 1$, Pengelompokan jenis sedang dengan bobot parameter $(w): 3$. Pengelompokan jenis berat dengan bobot parameter $(\mathrm{w}): 5$.

Tabel 2. Gejala Retardasi Mental

\begin{tabular}{cclc}
\hline NO & KG & Gejala & Bobot \\
\hline 1 & GRM01 & Penampilannya tidak seimbang & 3 \\
2 & GRM02 & Tidak bisa menjaga diriku sendiri & 1 \\
3 & GRM03 & Perkembangan pembicaraan selanjutnya & 3 \\
4 & GRM04 & Kurangnya perhatian terhadap lingkungan (tampilan & 1 \\
& & kosong) & 3 \\
5 & GRM05 & Gerakan biasanya tidak terkendali & 5 \\
6 & GRM06 & Air liur (cair) sering di dalam mulut & 3 \\
7 & GRM07 & Anggota tubuh kaku / lemah / lumpuh & 1 \\
8 & GRM08 & kesulitan bergerak & 5 \\
9 & GRM09 & Ada bagian anggota tubuh yang tidak sempurna & 3 \\
10 & GRM10 & Gerakannya kurang lancar & 1 \\
11 & GRM11 & Jari-jari tidak bisa digenggam dan kaku & 1 \\
12 & GRM12 & Menunjukkan postur tubuh yang tidak normal & 3 \\
13 & GRM13 & Terlalu aktif (ketidakmampuan untuk menenangkan & \\
& & diri) & 3 \\
14 & GRM14 & cenderung membangkang & 3 \\
15 & GRM15 & Iritabilitas / lekas marah & 5 \\
16 & GRM16 & Biasanya menunjukkan perilaku agresif, merusak, dan & mengganggu \\
17 & GRM17 & Seringkali melakukan tindakan yang melanggar & 5 \\
& & norma sosial / norma hukum & \\
\hline
\end{tabular}

Selanjutnya dari data gejala dan penyakit akan dilakukan pencocokan seperti Tabel 3:

Tabel 3. Relasi Gejala dan Penyakit

\begin{tabular}{ccccc}
\hline NO & Kode Gejala & \multicolumn{3}{c}{ Penyakit } \\
\cline { 3 - 5 } & & RM1 & RM2 & RM3 \\
\hline 1 & GRM01 & $*$ & & \\
2 & GRM02 & $*$ & & \\
3 & GRM03 & $*$ & & \\
4 & GRM04 & $*$ & & \\
5 & GRM05 & $*$ & $*$ & \\
6 & GRM06 & $*$ & $*$ & \\
7 & GRM07 & & $*$ & $*$ \\
8 & GRM08 & & $*$ & $*$ \\
9 & GRM09 & & $*$ & \\
10 & GRM10 & & & \\
11 & GRM11 & & & \\
12 & GRM12 & & & \\
13 & GRM13 & & & \\
14 & GRM14 & & & \\
15 & GRM15 & & & \\
16 & GRM16 & & & \\
17 & GRM17 & & & \\
\hline
\end{tabular}

Selain itu akan dirumuskan aturan main yang akan digunakan sebagai aturan analisis jawaban pasien. Berikut aturan yang telah ditetapkan: 
[R1] IF GRM01 AND GRM02 AND GRM03 AND GRM04 AND GRM05 AND GRM06 THEN RM1

[R2] IF GRM07 AND GRM08 AND GRM09 AND GRM10 AND GRM11 AND GRM12 AND GRM13 THEN RM2

[R3] IF GRM14 AND GRM15 AND GRM16 AND GRM17 THEN RM3 berikut:

Selanjutnya akan dibuatkan metode pembelajaran yang cocok untuk setiap penyakit sebagai

1. Tunagrahita

Strategi atau cara pembelajaran yang bisa direkomendasikan untuk digunakan untuk proses pembelajaran anak tunagrahita yakni cara atau strategi dalam pembelajaran yang dipersonalisasi. Mereka bisa melakukan proses belajar secara bersama di dalam kelas, namun keluasan dan kedalaman pada materi, metode dan teknik akan didasarkan pada kemampuan dan kebutuhan masing-masing siswa. Perbedaan. Namun dapat juga memakai strategi lain, seperti cara atau strategi kerjasama dan strategi modifikasi perilaku. Metode pengajaran sebaiknya dipilih agar anak belajar sambil melakukan, karena latihan stimulasi yang diperoleh melalui latihan akan cepat menjadi pusat berpikir dan tidak mudah dilupakan. Alat atau media pembelajaran yang digunakan oleh anak tunagrahita harus memperhatikan beberapa standar, misalnya: anak merespon pengetahuan yang telah dipelajari, tidak mudah rusak, tidak berbahaya, tidak abstrak, dapat digunakan oleh anak dan mudah diakses. Saat mempelajari anak tunagrahita, sebagian kecil materi pelajaran harus dipelajari terlebih dahulu, baru kemudian materi selanjutnya dievaluasi. Alat evaluasi harus berbentuk kinerja dan menangani hasilnya secara kualitatif. Sedangkan jika perlu penilaian kuantitatif dapat dilakukan dengan penjelasan singkat (intinya deskriptif)..

2. Tunadaksa

a. Prinsip multisensori (banyak indra)

Karena banyak anak tunagrahita menderita gangguan sensorik, maka proses mendidik anak tunagrahita sebanyak mungkin akan memanfaatkan dan mengembangkan indera yang ada pada anak. Melalui pendekatan multi-indera, kelemahan pada indera lain dapat digunakan untuk membantu memahami prosesnya.

c. Prinsip individualisasi

Personalisasi artinya titik awal pelayanan pendidikan adalah kemampuan setiap anak. Model layanan pendidikan bisa klasik atau individual. Dalam model klasik, layanan pendidikan diberikan kepada kelompok individu yang cenderung memiliki kemampuan yang hampir sama, dan materi pembelajaran diberikan kepada setiap anak sesuai dengan kemampuan masing-masing anak.

d. Penataan Lingkungan Belajar

Karena anak tunagrahita memiliki masalah gerak, maka pergi ke sekolah memerlukan peralatan khusus di lingkungan belajarnya. Gedung sekolah sebaiknya dilengkapi dengan ruangan / fasilitas tertentu agar dapat mendukung kelancaran kegiatan sekolah bagi anak difabel. Perancangan bangunan hendaknya mengutamakan tiga prioritas yaitu anak yang mudah dimasuki, anak yang mudah bergerak di dalam kamar, dan anak yang mudah menyesuaikan diri, atau semua barang yang ada di dalam ruangan mudah digunakan.

3. Tunalaras

Jika seorang anak tunalaras mengalami kesulitan beradaptasi, tindakan modifikasi perilaku yang spesifik dan terus menerus perlu dilakukan hingga ia dapat beradaptasi dengan lingkungan. Metode yang dapat digunakan adalah sebagai berikut: 
a. Satu jenis. Terapi bermain untuk anak-anak tunalaras.

b. Metode psikoanalitik dan metode psikoanalitik dipelajari bersama untuk membantu mengungkap dasar-dasar psikopatologi untuk meningkatkan fungsi psikologis yang tercermin dari perilaku dan prestasi.

c. Metode psikologi pendidikan, anak-anak cacat dengan gangguan jiwa, memiliki penyimpangan perilaku, sehingga prestasi akademik rendah. Melalui terapi bermain, kreativitas anak dapat dibina.

d. Pendekatan humanistik, program pendidikan untuk anak penyandang cacat bertujuan untuk meningkatkan keterampilan pengarahan diri sendiri. Kegiatan belajar di lingkungan demokratis terbuka dan menyenangkan.

e. Metode ekologis, anak penyandang disabilitas dianggap anak bermasalah, dan mereka menggunakan terapi bermain untuk mengubah perilaku yang tidak diharapkan.

f. Dari segi tingkah laku, anak konsisten dengan tingkah lakunya yang abnormal, dan tingkah lakunya nampaknya dianalisis sebagai modifikasi dari tingkah laku yang diharapkan.

Prosesnya dilakukan sebagai berikut:

1. Menentukan data yang akan dianalisis, dimana data yang akan dianalisis adalah data yang terdapat pada tabel yang ditunjukkan pada Tabel 4.

Tabel 4. Pertanyaan Gejala:

\begin{tabular}{clc}
\hline No & \multicolumn{1}{c}{ Gejala } & Jawaban \\
\hline 1 & Penampilannya tidak seimbang & $\mathrm{T}$ \\
2 & Tidak bisa menjaga diriku sendiri & $\mathrm{T}$ \\
3 & Perkembangan pembicaraan selanjutnya & $\mathrm{T}$ \\
4 & Kurangnya perhatian terhadap lingkungan (tampilan kosong) & $\mathrm{T}$ \\
5 & Gerakan biasanya tidak terkendali & $\mathrm{T}$ \\
6 & Air liur (cair) sering di dalam mulut & $\mathrm{T}$ \\
7 & Anggota tubuh kaku / lemah / lumpuh & $\mathrm{Y}$ \\
8 & kesulitan bergerak & $\mathrm{Y}$ \\
9 & Ada bagian anggota tubuh yang tidak sempurna & $\mathrm{Y}$ \\
10 & Gerakannya kurang lancar & $\mathrm{Y}$ \\
11 & Jari-jari tidak bisa digenggam dan kaku & $\mathrm{Y}$ \\
12 & Menunjukkan postur tubuh yang tidak normal & $\mathrm{Y}$ \\
13 & Terlalu aktif (ketidakmampuan untuk menenangkan diri) & $\mathrm{T}$ \\
14 & cenderung membangkang & $\mathrm{T}$ \\
15 & Iritabilitas / lekas marah & $\mathrm{T}$ \\
16 & Biasanya menunjukkan perilaku agresif, merusak, dan mengganggu & $\mathrm{T}$ \\
17 & Seringkali melakukan tindakan yang melanggar norma sosial / norma & $\mathrm{T}$ \\
& hukum & \\
\hline
\end{tabular}

Dari data konsultasi yang diinputkan tersebut akan dilakukan proses pencarian nilai kemiripan dengan metode $C B R$ yaitu dengan tahap sebagai berikut:

1. Tahap Retrieve yaitu Sistem akan mencari data pertumbuhan sebelumnya dan menaksir kesamaan atau kemiripan dengan data penyakit yang baru. Dimana data dahulu yang diambil adalah data dasar atau data gejala dan jenis penyakit secara keseluruhan yang ditampilkan pada Tanggal 5 . 
Tebel 5. Tahap Retrieve

\begin{tabular}{lllc}
\hline Kode Kasus & \multicolumn{1}{c}{ Jenis } & Gejala & Bobot \\
\hline RM1 & Tunagrahita & Penampilannya tidak seimbang & 3 \\
& & Tidak bisa menjaga diriku sendiri & 1 \\
& Perkembangan pembicaraan selanjutnya & 3 \\
& Kurangnya perhatian terhadap lingkungan (tampilan & 1 \\
& kosong) & \\
& Gerakan biasanya tidak terkendali & 3 \\
& Air liur (cair) sering di dalam mulut & 5 \\
Jumlah Bobot & & 16 \\
RM2 & Anggota tubuh kaku / lemah / lumpuh & 3 \\
& kesulitan bergerak & 1 \\
& Ada bagian anggota tubuh yang tidak sempurna & 5 \\
& Gerakannya kurang lancar & 3 \\
& Jari-jari tidak bisa digenggam dan kaku & 1 \\
& Menunjukkan postur tubuh yang tidak normal & 1 \\
Jumlah Bobot & Terlalu aktif (ketidakmampuan untuk menenangkan diri) & 3 \\
RM3 & cenderung membangkang & 17 \\
& Tunalaras & Iritabilitas / lekas marah & 3 \\
& Biasanya menunjukkan perilaku agresif, merusak, dan & 3 \\
& mengganggu & 5 \\
& Seringkali melakukan tindakan yang melanggar norma & 5 \\
\hline Jumlah Bobot & sosial / norma hukum & 16 \\
\hline
\end{tabular}

2. Reuse, yakni dengan memanfaatkan kembali permasalahan atau kasus yang ada pada basis data yang digunakan dengan mencoba melakukan pemecahan masalah atau kasus, sistem akan menyesuaikan kondisi kasus atau kasus lama dalam fase pengambilan keadaan saat ini.

Dimana gejala yang dialami oleh pasien adalah sebagai berikut:
a. Anggota tubuh kaku / lemah / lumpuh
b. kesulitan bergerak
c. Ada bagian anggota tubuh yang tidak sempurna
d. Gerakannya kurang lancar
e. Jari-jari tidak bisa digenggam dan kaku
f. Menunjukkan postur tubuh yang tidak normal

Dari kasus pasien baru maka akan dilakukan perbandingan dengan seluruh kasus penyakit yang lama, yaitu sebagai berikut :

Tabel 6. Tabel Perbandingan Kasus Baru dan Kasus Lama

\begin{tabular}{ccccccc}
\hline Kasus & $\begin{array}{c}\text { Kasus Lama } \\
\text { Jumlah } \\
\text { Gejala }\end{array}$ & Bobot & Kasus & $\begin{array}{c}\text { Jumlah } \\
\text { Gejala }\end{array}$ & $\begin{array}{c}\text { Jumlah Gejala } \\
\text { Mirip }\end{array}$ & Bobot \\
\hline RM1 & 6 & 16 & PSN1 & 7 & 0 & 17 \\
RM2 & 7 & 16 & PSN1 & 6 & 6 & 14 \\
RM3 & 4 & 16 & PSN1 & 7 & 0 & 17 \\
\hline
\end{tabular}

Dari tabel diatas maka akan dilakukan proses perhitungan CBR untuk mencocokan kemiripannya :

1. Pencocokan Dengan Kasus RM1

Dimana gejala yang dialami oleh pasien adalah sebagai berikut:

a. Anggota tubuh kaku / lemah / lumpuh 
JSAI : Journal Scientific and Applied Informatics

Vol. 4, No. 01, Januari 2021, hal. 95 105

E-ISSN: 2614-3054; P-ISSN: 2614-3062, accredited by Kemenristekdikti, Sinta 5

DOI: 10.36085

b. kesulitan bergerak

c. Ada bagian anggota tubuh yang tidak sempurna

d. Gerakannya kurang lancar

e. Jari-jari tidak bisa digenggam dan kaku

f. Menunjukkan postur tubuh yang tidak normal

Tabel 7. Pencocokan Dengan Gejala Kasus Lama RM1

\begin{tabular}{lc}
\hline \multicolumn{1}{c}{ Gejala Kasus Lama } & Kemiripan \\
\hline Penampilannya tidak seimbang & 0 \\
Tidak bisa menjaga diriku sendiri & 0 \\
Perkembangan pembicaraan selanjutnya & 0 \\
Kurangnya perhatian terhadap lingkungan (tampilan kosong) & 0 \\
Gerakan biasanya tidak terkendali & 0 \\
Air liur (cair) sering di dalam mulut & 0 \\
\hline
\end{tabular}

Ket : Jika Gejala Sama akan diberikan nilai 1 sedangkan tidak sama akan diberikan nilai 0

Dari persamaan gejala tersebut, persamaan dapat diketahui melalui rumus sebagai berikut:

Similarity (problem, case)

$$
=\frac{(s 1 * w 1)+(s 2 * w 2)+(s 3 * w 3)+(s 4 * w 4)+(s 5 * w 5)+(s 6 * w 6)}{w 1+w 2+w 3+w 4+w 5+w 6}
$$

dimana $\mathrm{s}=$ Bobot Kemiripan, $\mathrm{w}=$ bobot Gejala

$$
\begin{aligned}
& S(\text { problem }, \text { case })=\frac{(0 * 3)+(0 * 1)+(0 * 3)+(0 * 1)+(0 * 3)+(0 * 5)}{5+3+1+5+3+1} \\
& S(\text { problem, case })=\frac{0}{16}=0
\end{aligned}
$$

2. Pencocokan Dengan Kasus RM2

Dimana gejala yang dialami oleh pasien adalah sebagai berikut:
a. Anggota tubuh kaku / lemah / lumpuh
b. kesulitan bergerak
c. Ada bagian anggota tubuh yang tidak sempurna
d. Gerakannya kurang lancar
e. Jari-jari tidak bisa digenggam dan kaku
f. Menunjukkan postur tubuh yang tidak normal

Tabel 8. Pencocokan Dengan Gejala Kasus Lama RM2

\begin{tabular}{lc}
\hline \multicolumn{1}{c}{ Gejala Kasus Lama } & Kemiripan \\
\hline Anggota tubuh kaku / lemah / lumpuh & 1 \\
kesulitan bergerak & 1 \\
Ada bagian anggota tubuh yang tidak sempurna & 1 \\
Gerakannya kurang lancar & 1 \\
Jari-jari tidak bisa digenggam dan kaku & 1 \\
Menunjukkan postur tubuh yang tidak normal & 1 \\
Terlalu aktif (ketidakmampuan untuk menenangkan diri) & 0 \\
\hline
\end{tabular}

Ket : Jika Gejala Sama akan diberikan nilai 1 sedangkan tidak sama akan diberikan nilai 0 Dari persamaan gejala tersebut, persamaan dapat diketahui melalui rumus sebagai berikut:

$$
\begin{aligned}
& \text { Similarity (problem, case) } \\
& =\frac{(s 1 * w 1)+(s 2 * w 2)+(s 3 * w 3)+(s 4 * w 4)+(s 5 * w 5)+(s 6 * w 6)+(s 7 * w 7)}{w 1+w 2+w 3+w 4+w 5+w 6+w 7}
\end{aligned}
$$

dimana $\mathrm{s}=$ Bobot Kemiripan, $\mathrm{w}=$ bobot Gejala 


$$
\begin{aligned}
& S(\text { problem }, \text { case })=\frac{(1 * 3)+(1 * 1)+(1 * 5)+(1 * 3)+(1 * 1)+(1 * 1)+(0 * 3)}{3+1+5+3+1+1+3} \\
& S(\text { problem, case })=\frac{14}{17}=0,8235
\end{aligned}
$$

3. Pencocokan Dengan Kasus RM3

Dimana gejala yang dialami oleh pasien adalah sebagai berikut:
a. Anggota tubuh kaku / lemah / lumpuh
b. kesulitan bergerak
c. Ada bagian anggota tubuh yang tidak sempurna
d. Gerakannya kurang lancar
e. Jari-jari tidak bisa digenggam dan kaku
f. Menunjukkan postur tubuh yang tidak normal

Tabel 9. Pencocokan Dengan Gejala Kasus Lama RM3

\begin{tabular}{lc}
\hline Gejala Kasus Lama & Kemiripan \\
\hline cenderung membangkang & 0 \\
Iritabilitas / lekas marah & 0 \\
Biasanya menunjukkan perilaku agresif, merusak, dan mengganggu & 0 \\
Seringkali melakukan tindakan yang melanggar norma sosial / norma hukum & 0 \\
\hline
\end{tabular}

Ket : Jika Gejala Sama akan diberikan nilai 1 sedangkan tidak sama akan diberikan nilai 0 Dari persamaan gejala tersebut, persamaan dapat diketahui melalui rumus sebagai berikut:

Similarity (problem, case $)=\frac{(s 1 * w 1)+(s 2 * w 2)+(s 3 * w 3)+(s 4 * w 4)}{w 1+w 2+w 3+w 4}$ dimana $\mathrm{s}=$ Bobot Kemiripan, $\mathrm{w}=$ bobot Gejala

$$
\begin{aligned}
& S(\text { problem }, \text { case })=\frac{(0 * 3)+(0 * 3)+(0 * 5)+(0 * 5)}{3+3+5+5} \\
& S(\text { problem, case })=\frac{0}{16}=0
\end{aligned}
$$

Dari proses perhitungan pada kasus baru PSN1 dengan menggunakan metode CBR didapatkan hasil rekomendasi nilai pada Tabel 10.

Tabel 10. Hasil Nilai Rekomendasi

\begin{tabular}{ccc}
\hline Kode Penyakit & Jenis Penyakit & Nilai Rekomendasi \\
\hline RM1 & Tunagrahita & 0 \\
RM2 & Tunadaksa & 0,8235 \\
RM3 & Tunalaras & 0 \\
\hline
\end{tabular}

Dari tabel diatas maka dipastikan bahwa PSN1 mengalami penyakit Tunadaksa dengan nilai rekomendasi 0,8235 atau jika dipersentasekan $0,8235 * 100 \%=82,35 \%$. Sehingga metode pembelajaran yang cocok untuk penyakit tunadaksa adalah sebagai berikut:

a. Prinsip multisensori (banyak indra)

Karena banyak anak tunagrahita menderita gangguan sensorik, maka proses mendidik anak tunagrahita sebanyak mungkin akan memanfaatkan dan mengembangkan indera yang ada pada anak. Melalui pendekatan multi-indera, kelemahan pada indera lain dapat digunakan untuk membantu memahami prosesnya.

b. Prinsip individualisasi

Personalisasi artinya titik awal pelayanan pendidikan adalah kemampuan setiap anak. Model layanan pendidikan bisa klasik atau individual. Dalam model klasik, layanan pendidikan diberikan kepada kelompok individu yang cenderung memiliki kemampuan 
yang hampir sama, dan materi pembelajaran diberikan kepada setiap anak sesuai dengan kemampuan masing-masing anak.

c. Penataan Lingkungan Belajar

Karena anak tunagrahita memiliki masalah gerak, maka pergi ke sekolah memerlukan peralatan khusus di lingkungan belajarnya. Gedung sekolah sebaiknya dilengkapi dengan ruangan / fasilitas tertentu agar dapat mendukung kelancaran kegiatan sekolah bagi anak difabel. Perancangan bangunan hendaknya mengutamakan tiga prioritas yaitu anak yang mudah dimasuki, anak yang mudah bergerak di dalam kamar, dan anak yang mudah menyesuaikan diri, atau semua barang yang ada di dalam ruangan mudah digunakan.

\section{KESIMPULAN}

Dimulai dari tahap penelitian memilih tipe belajar anak Retardasi mental, dan berdasarkan proses analisis yang telah dilakukan maka dapat diambil kesimpulan sebagai berikut: Sistem pakar dapat melacak gejala yang dipilih oleh pengguna berdasarkan kondisi anak yang diamati. Hasil identifikasi dari contoh pada penelitian ini dengan gejala: anggota gerak tubuh kaku / lemah / lumpuh (GRM07), Kesulitan bergerak (GRM08), Ada bagian anggota tubuh yang tidak sempurna (GRM09), Gerakannya kurang lancar (GRM10), Jari-jari tidak bisa digenggam dan kaku (11), Menunjukkan postur tubuh yang tidak normal (GRM12). Dikarenakan nilai Tunadaksa (P2) lebih tinggi yaitu 0,8235 atau $82,35 \%$ maka sistem pakar menghasilkan identifikasi bahwa anak tersebut terkena penyakit Tunadaksa dengan nilai 0,8235 serta menghasilkan tipe belajar anak yang disarankan prinsip multisensori (banyak indra), prinsip individualisasi dan penataan lingkungan belajar. Melalui penelitian diatas penulis berharap terdapat peneliti lain melakukan penelitian lebih lanjut, dikarenakan keterbatasan waktu, terdapat beberapa bagian yang belum dibahas. Metode dan jenis gangguan Retardasi mental pada anak lainnya diharapkan dapat digunakan untuk mengembangkan sistem pakar ini.

\section{REFERENSI}

[1] S. R. Trisno, Muhammad Riandi Widiyantoro, "Penerapan Jaringan Saraf Tiruan Untuk Menghitung Nilai Kandungan Makanan,” JSAI J. Sci. Appl. Informatics, vol. 3, no. 3, pp. 115-121, 2020.

[2] A. A. P. Gunawan, "PemanfaatanTeknologi Augmented Reality Edukasi Pengenalan Hewan Vivipar Ovipar Dan Ovovivipar Bagi Siswa Sekolah Dasar," JSAI J. Sci. Appl. Informatics, vol. 3, no. 3, pp. 137-148, 2020.

[3] F. Siti andini utiarahman, "Identifikasi Kerusakan Mobil Menggunakan Sistem Pakar Berbasis Metode Forward Chaining Pada Global Motor Gorontalo," JSAI, vol. 3, no. 1, pp. 19-24, 2020.

[4] D. R. Habibie and D. Aldo, "Sistem Pakar Untuk Identifikasi Jenis Jerawat Dengan Metode Certainity Factor," JOINTECS (Journal Inf. Technol. Comput. Sci., vol. 4, no. 3, p. 79, 2019, doi: 10.31328/jointecs.v4i3.1055.

[5] D. Aldo and D. Riliyanda, "Aplikasi Sistem Pakar Dalam Mendiagnosa Penyakit Infertilitas Pada Pria," vol. 7, no. 1, pp. 20-31, 2019.

[6] Z. M. Dasril Aldo, "Aplikasi Identifikasi Penyakit Ikan Laut Menggunakan Metode Case Based Reasoning," J. Sains dan Inform., vol. 6, no. 2, pp. 78-83, 2020, doi: 10.22216/jsi.v4i1.

[7] M. F. Suryana, F. Fauziah, and R. T. K. Sari, "Implementasi Sistem Pakar Menggunakan Metode Certainty Factor Untuk Mendiagnosa Dini Corona Virus Desease (COVID-19)," J. Media Inform. Budidarma, vol. 4, no. 3, p. 559, 2020, doi: 10.30865/mib.v4i3.2132.

[8] E. D. Widianto, Y. W. Zaituun, and I. P. Windasari, "Aplikasi Sistem Pakar Pendeteksi Penyakit Tuberkulosis Berbasis Android," khazanah Inform., vol. 4, no. 1, pp. 47-54, 2018.

[9] H. T. Sihotang, T. Informatika, and S. Utara, "Sistem pakar untuk mendiagnosa penyakit pada tanaman jagung dengan metode bayes," J. Inform. Pelita Nusant., vol. 3, no. 1, 2018.

[10] Minarni, I. Warman, and W. Handayani, "Case-Based Reasoning (CBR) pada Sistem Pakar 
Identifikasi Hama dan Penyakit Tanaman Singkong dalam Usaha Meningkatkan Produktivitas Tanaman Pangan," J. TEKNOIF, vol. 5, no. 1, pp. 41-47, 2017, doi: 10.21063/JTIF.2017.V5.1.4147.

[11] Y. Wendra and D. Aldo, "Metode Case Based Reasoning Untuk Identifikasi Penyakit Tanaman Padi," Jursima, vol. 8, no. 2, pp. 103-110, 2020.

[12] R. M. Candra and J. S. Wirman, "Sistem Diagnosa Kegagalan dalam Budidaya Ikan Konsumsi Air Tawar dengan Menggunakan Metode Case Based Reasoning," J. Sains, Teknol. dan Ind., vol. 14, no. 2, pp. 144-149, 2017.

[13] N. Ritha and M. Sutoyo, "Case Based Reasoning Untuk Mendeteksi Kerusakan Harddisk," J. Sustain., vol. 5, no. 01, pp. 15-21, 2016.

[14] A. S. Bararah, Ernawati, and D. Andreswari, "Implementasi Case Based Reasoning Untuk Diagnosa Penyakit Berdasarkan Gejala Klinis Dan Hasil Pemeriksaan Hematologi Dengan Probabilitas Bayes ( Studi Kasus : RSUD Rejang Lebong )," Rekursif, vol. 5, no. 1, pp. 43-54, 2017.

[15] R. Adawiyah, "Case Based Reasoning Diagnosis Hama dan Penyakit Tanaman Nilam," Intensif, vol. 2, no. 1, p. 57, 2018, doi: 10.29407/intensif.v2i1.11829. 